\title{
THE CCB TREATMENT OF SIXTEEN INDONESIAN WOOD SPECIES AGAINST MARINE BORERS
}

\author{
Mohammad Muslich ${ }^{1}$
}

\begin{abstract}
This study was conducted to provide basic information on the treatment of some wood species using a copper bichromated boron (CCB). The specimens were treated with CCB for 2 hours in a 150 psi of full cell process. The treated and untreated wood samples were tested against marine borers for 4 , 8 and 12 months. The results indicated that full cell process with CCB were able to prevent marine borers attack. Untreated wood specimens were susceptible to marine borers attack, except lara (Metrosideros petiolata Kds.) and kandole (Diploknema oligomera H.J.L.). The attacking borers are Martesia striata Linn of the Pholadidae family, Teredo bartschi Clapp., Dicyathifer manni Wright and Bankia cieba Clench. of the Teredinidae family. However, crustaceans were found clinging to the wood specimens when they were taken from the sea. These crustaceans belongs to Sphaeromatidae family.
\end{abstract}

Keywords: Wood, marine borers, CCB, full process, crustaceans

\section{INTRODUCTION}

Marine borers, as they are commonly known, attack harbor pilling, boats, and any other structural timbers in the sea or brackish water. Marine borers are widely distributed throughout the world, and are especially active in tropical sea. Two common organism of marine borers are mollusk and crustacean, the latter known as "shipworm" and "gribble". Type of their attack is characterized by the form of wood damage.

It is estimated that 4,000 wood species grown in Indonesia, and almost all of them have durability class of III-V (Oey, 1964). They are not resistant against marine borers attack. The resistance of wood to marine borers attack varies from one species to others. This is mainly caused by its variation in natural properties of the wood species themselves. Bianchi (1933) and Gongrijp (1932) reported that the resistance to marine borers attack depends on its density or hardness, silica and toxic extractive contents. The suitability of non-durable wood species used in a condition with high risk of marine borers attack depends on the treatability of the wood species. Some of wood species are highly treatable and some others are refractory.

Usually the wood used for construction purposes has a durability class of I-II such as ulin (Eusideroxylon zwageri T. et B.), laban (Vitex pubescens Vahl.), teak (Tectona grandis L.f.), merbau (Instia bijuga O.Ktze.), and so on. The demands of the wood for those purposes increase from year to year, while its supply affords less and less, so that other species need to be explored to be used as substitutes.

${ }^{1}$ Forest Products Research and Development Center, Bogor 
This study is intended to provide basic information on the treatment of wood using a CCB preservative. The information is beneficial to the assessment of those wood species for ship building or marine construction. Accordingly, the durability of wood species to preservative retention and penetration, and the intensity of marine borer attack were evaluated in this study.

\section{MATERIAL AND METHODS}

Sixteen Indonesian wood species were used in the experiment, they were (1) Ampupu (Eucalyptus deglupta Bl.), (2) Jati (Tectona grandis L.f.), (3) Johar (Cassia siamea Lamp.), (4) Kandole (Diploknema oligomera H.J.L.), (5) Kemiri (Aleurites moluccana L.Wild.), (6) Kempas (Bouea burmanica Griff.), (7) Keruing (Dipterocarpus retusus Bl.), (8) Kolaka (Parinari corymbosa Miq.), (9) Lara (Metrosideros petiolata Kds.), (10) Mahoni (Swietenia macrophylla King.), (11) Marasi (Hymenaea courbaril L.), (12) Meranti (Shorea spp.), (13) Merbau (Intsia bijuga O.Ktz.), (14) Nyatoh (Palaqium obtusifolium Burck.), (15) Pulai (Alstonia scbolaris R.Br.), (16) Tanjung (Mimusops elengi L.) selected from Sulawesi. Thirty-five (35) smoothly planed wood specimens sized $2.5 \mathrm{~cm}$ by $5 \mathrm{~cm}$ in cross section by $30 \mathrm{~cm}$ in longitudinal direction were prepared for each species, totally 560 specimens for the over all 16 wood species. A one centimeter diameter hole was made at the middle of the samples.

Three hundred twenty of 560 specimens were impregnated with 3\% copper bichromated boron (CCB) using 150 psi full process. Wood preservative retention was calculated for its weight differences before and after treatment. After treatment, five treated wood samples of each species were selected to measure the assessment of preservative penetration. The samples were cross cut at $5 \mathrm{~cm}$ distance from both ends of the samples. The cut surface area was subsequently sprayed with reagents. The extent of penetration conducted by spot test of the $\mathrm{Cu}$ (Copper chemical) and it could be determined after the specimen was sprayed with chrome azurol solution. The present of $\mathrm{Cu}$ can be determined when the color of the wood turns into dark blue. The IUFRO method (Smith and Tablyn, 1970) was applied for the determination of wood treatability classes. The classification of treatability was shown in Table 1.

Table 1. Classification of wood treatability

\begin{tabular}{ll}
\hline Class & Penetration \\
\hline A (easy) & over $90 \%$ \\
B (moderate) & $50-90 \%$ \\
C (difficult) & $10-50 \%$ \\
D (very difficult) & less than $10 \%$ \\
\hline
\end{tabular}

Source : Smith and Tamblyn, 1970

Five treated samples were prepared for each species and exposed into marine borers for 4, 8 and 12 months. Five untreated wood samples for each species were also prepared as control. The treated and untreated wood samples were fixed together in a plastic cord, arranged into a raft and then exposed to the Ballang Lompo Island waters, located about 50 
$\mathrm{km}$ to the east of Makassar (South Sulawesi), for 4, 8 and 12 months. At the end of the experiment, the samples were split into two parts to determine marine borer infestation. The Nordic Wood Preservation Council (NWPC) Standard No. 1.4.2.2/75 was used to determine the intensity of infestation. The marine borers were identified from the traces of boring holes, form of cutting and pallet on the infested samples. To evaluate the intensity of borer attack the criteria adopted was shown in Table 2.

Table 2. The intensity of borer attack

\begin{tabular}{lc}
\hline Wood condition & Intensity of borer attack \\
\hline No attack & $0=<1 \%$ \\
Light attack & $1 / 3=133 \%$ \\
Medium attack & $2 / 3=3466 \%$ \\
Heavy attack & $1=>67 \%$ \\
\hline
\end{tabular}

Source: Turner, 1971

The marine borer species could be identified from the traces of the boring holes. The traces could be observed by cutting the pallet of the attacked samples. The marine borers were identified based on the marine borers classification by Turner (1971).

\section{RESULTS AND DISCUSSION}

\section{A. CCB Retention and Penetration}

Copper-bichromated boron (CCB) retention and penetration in each species of wood specimens are presented in Table 3. Most of the sixteen Indonesian wood species exhibit a wide differences in retention and penetration. The results revealed that 2 of the species were classified as easy, 2 species were moderate, 10 species were difficult and the remaining 2 species were very difficult. Kemiri (Aleurites moluccana L.Wild.), pulai (Alstonia scholaris R.Br.) were more permeable than other wood species, so that the preservative retention and penetration $\mathrm{CCB}$ were greater and deeper. $\mathrm{CCB}$ retention and penetration in those wood species were $36.23 \mathrm{~kg} / \mathrm{m}^{3} ; 95.50 \%$ and $30.75 \mathrm{~kg} / \mathrm{m}^{3} ; 90.15 \%$ respectively. The corresponding values, especially for lara (Metrosideros petiolata Kds.) its CCB retention and penetration were respectively $0.50 \mathrm{~kg} / \mathrm{m}^{3} ; 2.60 \%$ and for kandole (Diploknema oligomera H.J.L.) were $0.60 \mathrm{~kg} / \mathrm{m}^{3}$; $2.50 \%$ are much lower and shallow.

The difference in retention and penetration was due to the difference in natural properties and extractive contents of wood species. Woods with lower extractive contents are of great importance as far as wood preservation is concerned. Also woods with lower extractive content are more permeable to liquids even after the woods have been felled and the timber has been seasoned, this means that it can be easily impregnated with preservative. It is a fortunate coincidence that the wood with lower extractive content is so readily permeable by liquids (Findlay, 1985). On the other hand, woods with higher extractive content become so choked with gummy materials, and the vessels are blocked with the bladder-like outgrowths, which are called tyloses. 
Table 3. Retention $\left(\mathrm{kg} / \mathrm{m}^{3}\right)$ and penetration (\%) of Copper-Chrome-Boron in sixteen wood species

\begin{tabular}{|c|l|c|c|l|}
\hline No. & \multicolumn{1}{|c|}{ Wood species } & $\begin{array}{c}\text { Retention } \\
\left(\mathrm{kg} / \mathrm{m}^{3}\right)\end{array}$ & $\begin{array}{c}\text { Penetration } \\
(\%)\end{array}$ & Treatability class \\
\hline 1. & Ampupu (Eucalyptus deglupta Bl.) & 6.87 & 35.05 & C (difficult) \\
2. & Jati (Tectona grandis L.f.) & 7.20 & 40.75 & C (difficult) \\
3. & Johar (Cassia siamea Lamp.) & 5.75 & 25.75 & C (difficult) \\
4. & Kandole (Diploknema oligomera H.J.L.) & 3.60 & 7.50 & D (very difficult) \\
5. & Kemiri (Aleurites moluccana L.Wild.) & 36.23 & 95.50 & A (easy) \\
6. & Kempas (Bouea burmanica Griff.) & 5.65 & 20.50 & C (difficult) \\
7. & Keruing (Dipterocarpus retusus Bl.) & 7.95 & 50.15 & B (moderate) \\
8. & Lara (Metrosideros petiolata Kds.) & 2.45 & 5.25 & D (very difficult) \\
9. & Mahoni (Swietenia macrophylla King.) & 7.48 & 39.25 & C (difficult) \\
10. & Marasi (Hymenaea courbaril L.) & 8.15 & 50.75 & B (moderate) \\
11. & Meranti (Shorea spp.) & 6.15 & 30.10 & C (difficult) \\
12. & Merbau (Intsia bijuga O.Ktz.) & 7.25 & 29.50 & C (difficult) \\
13. & Kolaka (Parinari corymbosa Miq.) & 5.50 & 27.60 & C (difficult) \\
14. & Nyatoh (Palaqium obtusifolium Burck.) & 15.69 & 40.05 & B (moderate) \\
15. & Pulai (Alstonia scholaris R.Br.) & 30.75 & 90.15 & A (easy) \\
16. & Tanjung (Mimusops elengi L.) & 6.65 & 25.95 & C (difficult) \\
\hline
\end{tabular}

Siau (1971) mentioned that the extractive substance was one of the inhibiting factors in the preservative permeability. Wilkinson (1979) found that the variations in permeability were particularly marked in heartwood on transition from sapwood. Also, passage in the cells of hardwoods and softwoods may become blocked, restricting the penetration of preservative. In some hardwoods, the blocking of the vessels occurs as a results of the outgrowths, known as tyloses. These are common to species with the cell-wall pits of large diameter such as the eucalypts and merantis. In species with small cell-wall pits such as the mahoganies, the blocking of the vessels occurs as a result of physiological activities of ray parenchyma adjacent to them, secreting tannin or gum-like substances through the common cell-wall pits between the parenchyma and the vessels (Muslich, 1994). Siau (1971) said that tyloses were usually found in heartwood, depending upon the species. Gummy substances, such as the reddish deposits in honey-locust heartwood and black material in ebony, may also occlude the vessels. Chalky deposits are also found in mahoni and jati.

\section{B. Resistance of Untreated Wood Species}

Results of the experiment reveal that there were different intensity of marine borer attack depending on the duration of exposure to sea waters. Most of the untreated samples were severely attacked by the marine bores after 4-month exposure, particularly kemiri (Aleurites moluccana L.Wild.), pulai (Alstonia scholaris R.Br.) and meranti (Shorea spp.). Light 
attack was frequently found on ampupu (Eucalyptus deglupta B1.), marasi (Hymenaea courbaril L.), nyatoh (Palaqium obtusifolium Burck.), keruing (Dipterocarpus retusus B1.), mahoni (Swietenia macrophylla King.) and johar (Cassia siamea Lamp.). Merbatu (Parinari corymbosa Miq.), jati (Tectona grandis L.f.), kempas (Bouea burmanica Griff.) tanjung (Mimusops elingi L.) and merbau (Intsia bijuga O.Ktz.) were resistant for 8 months, while kandole (Diploknema oligomera H.J.L.) and lara (Metrosideros petiolata Kds.) were resistant for 12 months (Table 2). The intensity of marine borer infestation is shown in Figure 1.

Table 4. The intensity of marine borers attack on test sample

\begin{tabular}{|c|c|c|c|c|c|c|c|c|}
\hline \multirow{3}{*}{ No. } & \multirow{3}{*}{ Wood species } & \multirow{3}{*}{$\begin{array}{c}\text { Specific } \\
\text { gravity }\end{array}$} & \multicolumn{6}{|c|}{ Attack intensity (\%) } \\
\hline & & & \multicolumn{2}{|c|}{4 months ${ }^{1)}$} & \multicolumn{2}{|c|}{8 months ${ }^{1)}$} & \multicolumn{2}{|c|}{12 months ${ }^{1)}$} \\
\hline & & & Control & Treated & Control & Treated & Control & Treated \\
\hline 1. & $\begin{array}{l}\text { Ampupu } \\
\text { (Eucalyptus deglupta } \mathrm{Bl} \text {.) }\end{array}$ & 0.57 & 50.00 & 0.00 & 75 & 0.00 & $\mathrm{x}$ & 3.75 \\
\hline 2. & $\begin{array}{l}\text { Jati } \\
\text { (Tectona grandis L.f.) }\end{array}$ & 0.65 & 6.50 & 0.00 & 30.65 & 0.00 & 45.59 & 0.00 \\
\hline 3. & $\begin{array}{l}\text { Johar } \\
\text { (Cassia siamea Lamp.) }\end{array}$ & 0.84 & 30.00 & 0.00 & 65.00 & 0.00 & 0.00 & 0.00 \\
\hline 4. & $\begin{array}{l}\text { Kandole } \\
\text { (Diploknema oligomera H.J.L.) }\end{array}$ & 1.12 & 0.00 & 0.00 & 0.00 & 0.00 & 0.00 & 0.00 \\
\hline 5. & $\begin{array}{l}\text { Kemiri } \\
\text { (Aleurites moluccana L.Wild.) }\end{array}$ & 0.31 & 85.00 & 0.00 & $\mathrm{X}$ & 0.00 & - & 0.00 \\
\hline 6. & $\begin{array}{l}\text { Kempas } \\
\text { (Bouea burmanica Griff.) }\end{array}$ & 1.02 & 7.15 & 0.00 & 30.00 & 0.00 & 45.75 & 0.00 \\
\hline 7. & $\begin{array}{l}\text { Keruing } \\
\text { (Dipterocarpus retusus } \mathrm{Bl} . \text { ) }\end{array}$ & 0.75 & 50.20 & 0.00 & 85.00 & 0.00 & $\mathrm{X}$ & 0.00 \\
\hline 8. & $\begin{array}{l}\text { Lara } \\
\text { (Metrosideros petiolata Kds.) }\end{array}$ & 1.15 & 0.00 & 0.00 & 0.00 & 0.00 & 0.00 & 0.00 \\
\hline 9. & $\begin{array}{l}\text { Mahoni } \\
\text { (Swietenia macrophylla King.) }\end{array}$ & 0.61 & 35.00 & 0.00 & 80.00 & 0.00 & 95.00 & 3.50 \\
\hline 10. & $\begin{array}{l}\text { Marasi } \\
\text { (Hymenaea courbaril L.) }\end{array}$ & 0.63 & 40.20 & 0.00 & 75.25 & 0.00 & 90.25 & 1.25 \\
\hline 11. & $\begin{array}{l}\text { Meranti } \\
\text { (Shora spp.) }\end{array}$ & 0.51 & 68.10 & 0.00 & $\mathrm{X}$ & 0.00 & - & 5.50 \\
\hline 12. & $\begin{array}{l}\text { Merbau } \\
\text { (Intsia bijuga O.Ktz.) }\end{array}$ & 0.84 & 14.40 & 0.00 & 38.30 & 0.00 & 53.80 & 2.75 \\
\hline 13. & $\begin{array}{l}\text { Merbatu } \\
\text { (Parinari corymbosa Miq.) }\end{array}$ & 0.96 & 4.25 & 0.00 & 25.75 & 0.00 & 40.00 & 0.00 \\
\hline 14. & $\begin{array}{l}\text { Nyatoh } \\
\text { (Palaqium obtusifolium Burck.) }\end{array}$ & 0.56 & 40.25 & 0.00 & 85.00 & 0.00 & 90.15 & 0.00 \\
\hline 15. & $\begin{array}{l}\text { Pulai } \\
\text { (Alstonia scholaris R.Br.) }\end{array}$ & 0.38 & 80.00 & 0.00 & $\mathrm{X}$ & 0.00 & - & 0.00 \\
\hline 16. & $\begin{array}{l}\text { Tanjung } \\
\text { (Mimusops elingi } \quad \text { L.) }\end{array}$ & 1.00 & 7.00 & 0.00 & 37.25 & 0.00 & 50.00 & 0.00 \\
\hline
\end{tabular}

Remarks: $\mathrm{X}=$ destroyed

- = completely destroyed

1) $=$ duration of exposure 
The difference in wood resistance against borer attack is due to the difference in natural properties of wood species. Silica content, wood strength or density and poisonous extractive substances could reduce or inhibit marine borer attack (Bianchi, 1933; Gongrijp, 1932; Southwell and Bultman, 1971). Silica could minimally reduce the marine borer attack by $0.5 \%$. Bianchi (1932) carried out a study on wood resistance of several wood species against marine borers in Indonesia. The results of this study showed that kolaka wood (Parinari corymbosum Drig.) and teak wood (Tectona grandis L.f.) containing silica $0.9 \%$ and $0.4 \%$ respectively, were highly resistant to marine borers.

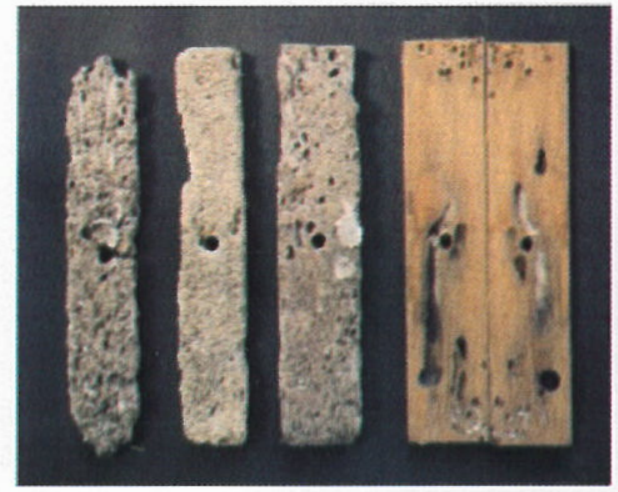

a b

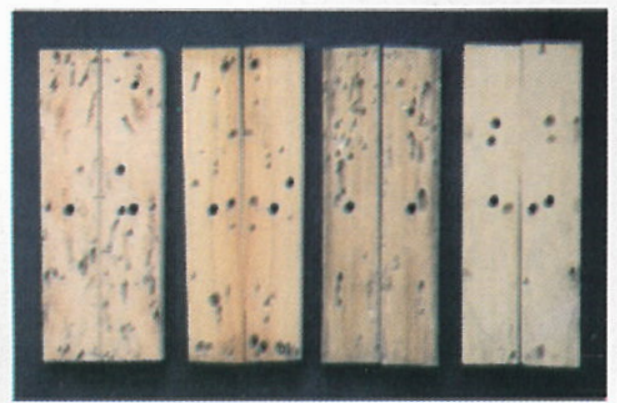

i c

$\mathrm{k}$ d

1

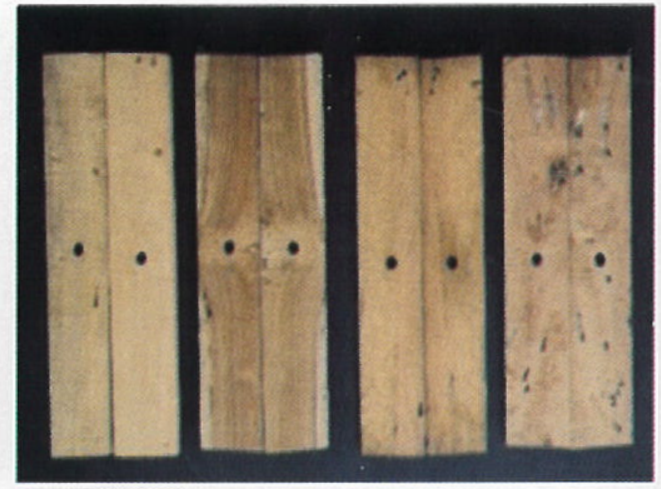

e

f

$\mathrm{g}$

h

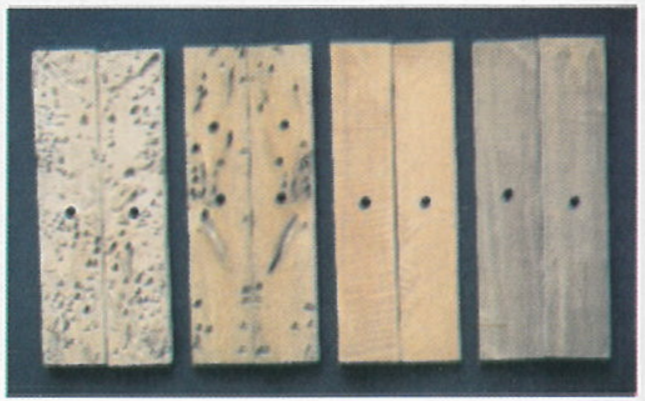

$\mathrm{m}$

o

$\mathrm{p}$

Figure 1. Intensity of marine borer infestation on untreated wood species after eight months exposure in the sea

Remarks: a. kemiri; b. pulai; c. meranti; d. merbau; e. kolaka; f. jati; g. tanjung; h. kempas; i. keruing; j. mahon; k. marasi; l. nyatoh; m. ampupu; $n$. johar; o. kandole; p. lara 
Silica content, wood strength or density and extractive substances were strongly influenced by wood growth process and growth pattern which were also affected by the environmental factors and heredity (Panshin and de Zeeuw, 1980). These two factors may affect the construction process of the wood elements, so that the silica content, extractive substance, specific weight, and height level also influence the wood resistance against marine borers. Wilkinson (1979) stated that the sapwood of any kind of wood was easily attacked by marine borers, while the heartwood was more resistant. The resistance of heartwood tends to be at a maximum in the outer heartwood and decreased inward to the pith.

Field experiments revealed that untreated wood species were attacked by teredinid species. The teredinids damage wood for food source, so that the extent of attack can reach the interior part of the sample wood. Turner (1966) stated that the genus Teredo and Bankia possessed an enzyme able to digest cellulose, so that the cellulose in the wood can be converted into a more readily digestible food. The teredinids develop faster in wood species containing high cellulose with less hardness and low silica content.

\section{Effectiveness of Copper Bichromated Boron}

Most of the specimens treated with CCB by a 150 psi full-cell process for two hours, were resistant for 12 months. After twelve months only few specimens were damaged. Light attack was frequently found on ampupu (Eucalyptus deglupta Bl.), merbau (Intsia bijuga O.Ktz.), mahoni (Swietenia macropbylla King.), meranti (Shorea spp.) and marasi (Hymenaea courbaril L.). It indicated that copper bichromated boron preservative was more effective for kemiri (Aleurites moluccana L.Wild.), pulai (Alstonia scholaris R.Br.), keruing (Dipterocarpus retusus Bl.) and nyatoh (Palaqium obtusifolium Burck.). The difference in the resistance of treated wood against marine borers was due to the difference in retention and penetration rate of CCB preservatives. Figure 2 shows the different intensity of marine borers infestation on treated and untreated wood species.

Preservative with low retention and penetration will be easily washed out by sea water, so that the wood samples can be easily attacked by marine borers. In this case, kemiri, pulai, keruing and nyatoh were more permeable than ampupu, merbau, mahoni, meranti and marasi, so that $\mathrm{CCB}$ retention was high and the penetration was also deeper. This means that although kemiri and pulai do not have high silica content, the attack by marine borer could be reduced by high preservative content with high retention and deep penetration. The attack of marine borers on other wood species could also be reduced as long as the wood species themselves contain poisonous extractive substances. Bianchi (1933) proved that teruntum wood (Lumnitzera littorea Voight.) and bungur wood (Lagerstromia speciosa Pers.) were resistant to marine borer attack although they did not contain silica. 


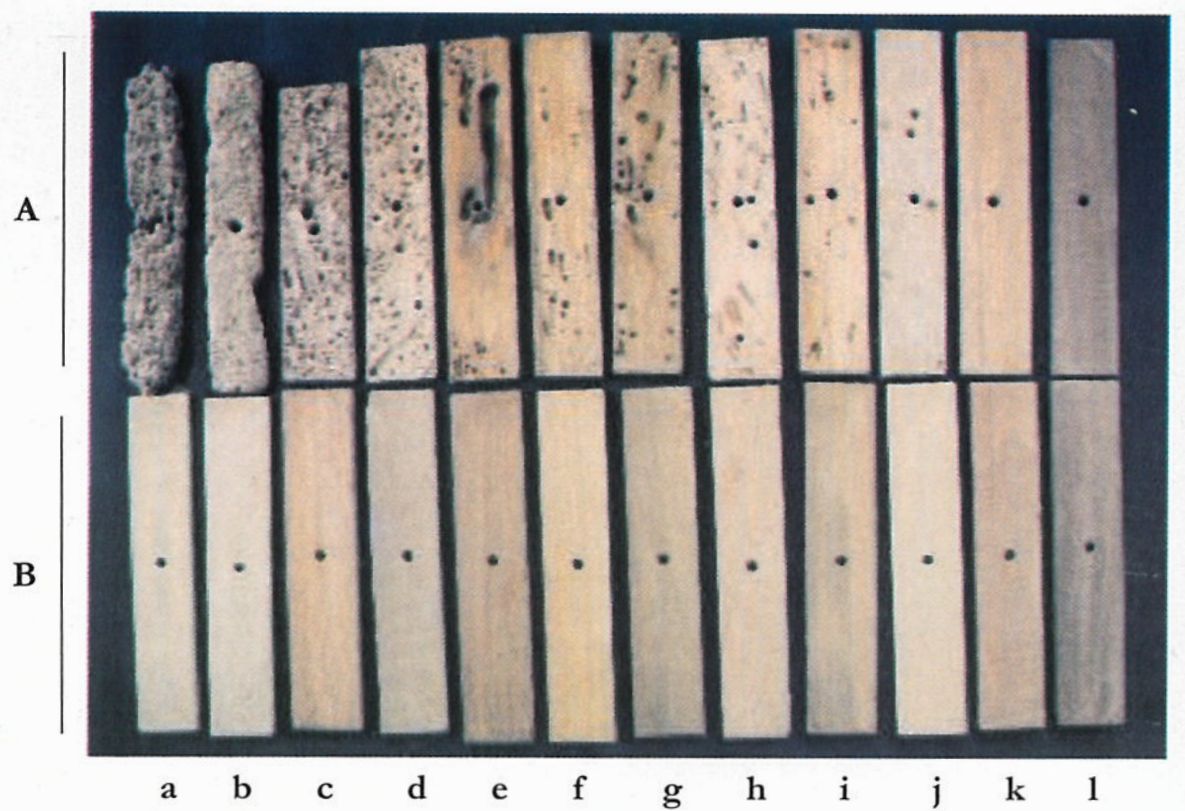

Figure 2. Intensity of marine borer infestation on untreated (A) and treated (B) wood species after eight months in the sea

Remarks: a. kemiri; b. pulai; c. meranti; d. ampupu; e. merbau; f. marasi; g. johor; h. keruing; i. kempas; j. merbatu; k. kandole; l. lara

Wood species with low extractive content were readily attacked by marine bores. However, these wood species were very permeable eventhough they were already dry. This means that they were easily impregnated with preservative solutions. It is fortunate that the low extractive containing-wood species are permeable to liquids. Nevertheless, the most vulnerable part of the timber is also the most easily protected (Findlay, 1985).

\section{Identification of Marine Borers Attack}

Marine borers which had attacked the wood specimens in the sea of Ballang Lompo Island were Martesia striata Line of Pholadidae family, Teredo bartschi Clapp., Dicyathifer manni Wright., and Bankia cieba Clench. of Terdinidae family. There were no symptoms of crustacean infestation on the wood specimens. However crustacean were found clinging to the wood specimens when they were taken from the sea. This crustacean belongs to Sphaeromasp.

\section{Pholadidae}

Martesia striata Linne. was one of the species found in the wood specimens treated for 12 months in the sea of Mallang Lompo Island. Martesia striata Linne. belongs to the Pholadidae 
family. It is a topical bivalve shell with the soft body enclosed within the shell itself. Martesia striata Linne. can be recognized from the structure of its shell. The shell is white in color, brittle in texture and, resembles a clam. It has radial grooves, and its end has chinks which are not grooved (Figure 3).

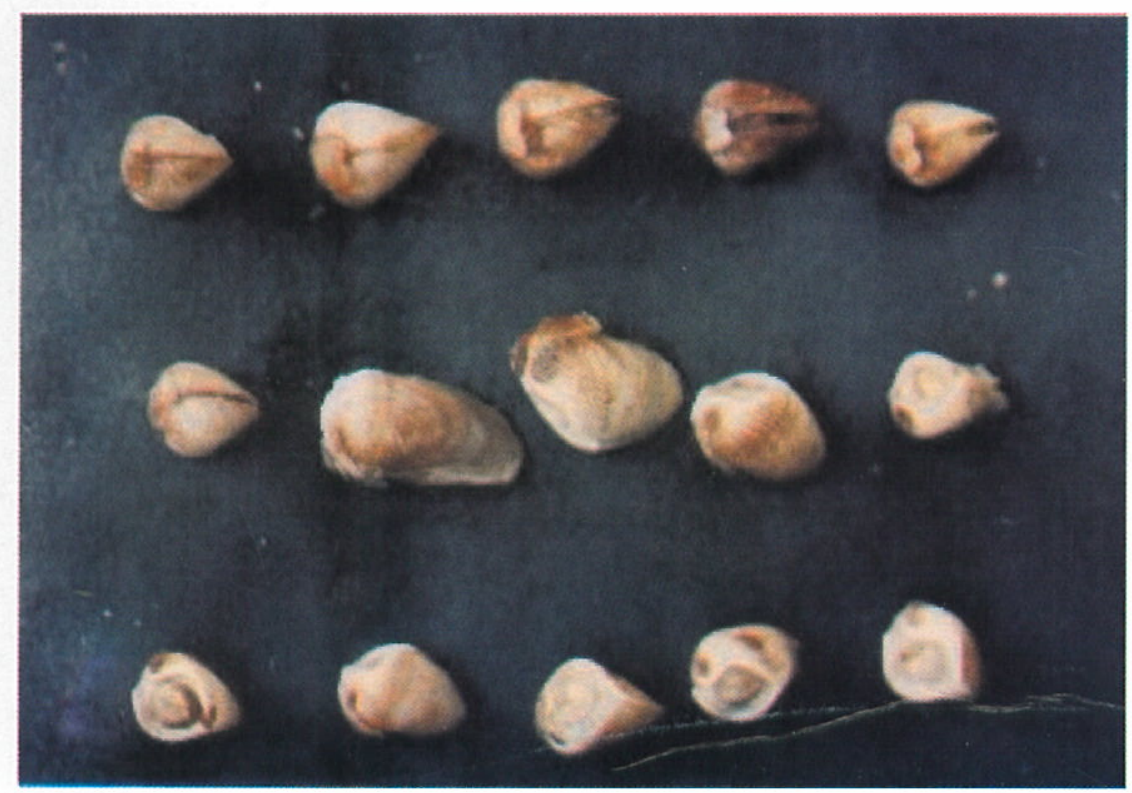

Figure 3. Martesia striata Linne

Pholadidae burrowed the wood specimens at right-angles to their surface. The length and diameter of the burrow were related to the size of the shell. Pholadidae infestation was easily recognized from the erosion inflicted on the specimen surface they made. Pholadidae tended to attack the wood only for their place to stay, so that most of the wood specimens were attacked by this family.

Although the type of Pholadidae in infestation was not as severe as Teredinidae infestation, it does not mean that Pholadidae infestation can be neglected. Norman and Henningsson (1975) stated that in the sea where Pholadidae population was high, all kinds of woods would be attacked by this organism. Southwell and Bultman (1971) said that woods which were naturally and highly resistant to Teredinidae actually were not resistant to Pholadidae. It was also said that Pholadida had fewer genera than Teredinidae, but the former was distributed more widely. Creatures in deep sea such as the Pholadidae were also known to cause damage to wires, and were also known as stone borers. This is probably the reasons why Pholadidae infestation on particular woods and seas are found more frequently than that of Teredinidae. 


\section{Teredinidae}

Other species found on the wood specimens were Teredo bartschi Clapp., Dicyatyfer manni Wright. and Bankia cieba Clench. of Teredinidae family. Teredo and Bankia are commonly known as "teredine borers" or "shipworm". Their bodies are soft, elongated, and worm-like. Their heads are crescent-shaped and hard, usually called "shell" and have files to bore the wood. At the posterior, the hard shells can be found formming like an oar which is called pallet. This pallet is very important in the identification of marine borers. For their metabolism and communication Teredo and Bankia use a pair of siphons which can be stuck in and out, and covered under the pallet.

The characteristics of Teredo bartschi Clapp. are as follows: the pallet is horn-like, blade without ridge at mid point, calcareous portion not extending to the tip but visible internally, inside of cup covered by periostracum, distal margin of inner face U-shaped, outer face U-Vshaped, periostracum a golden to dark brown and often extending laterally as small horns. The characteristics of Dicyatifer manni Wright. are as follows: the blade of pallet about as wide as its length, moderately cupped, with a medial ridge partially or completely dividing it, distal margin on outer face U-shaped, and on inner face nearly straight. The characteristics of Bankia cieba Clench. are as follows: the type of pallet is margin of serrated cones, distal margin of calcareous portion of cone nearly straight, serrations short and fin on outer face, long and thin on inner face. The tredinids which attacked the wood specimens are shown in Figure 4.

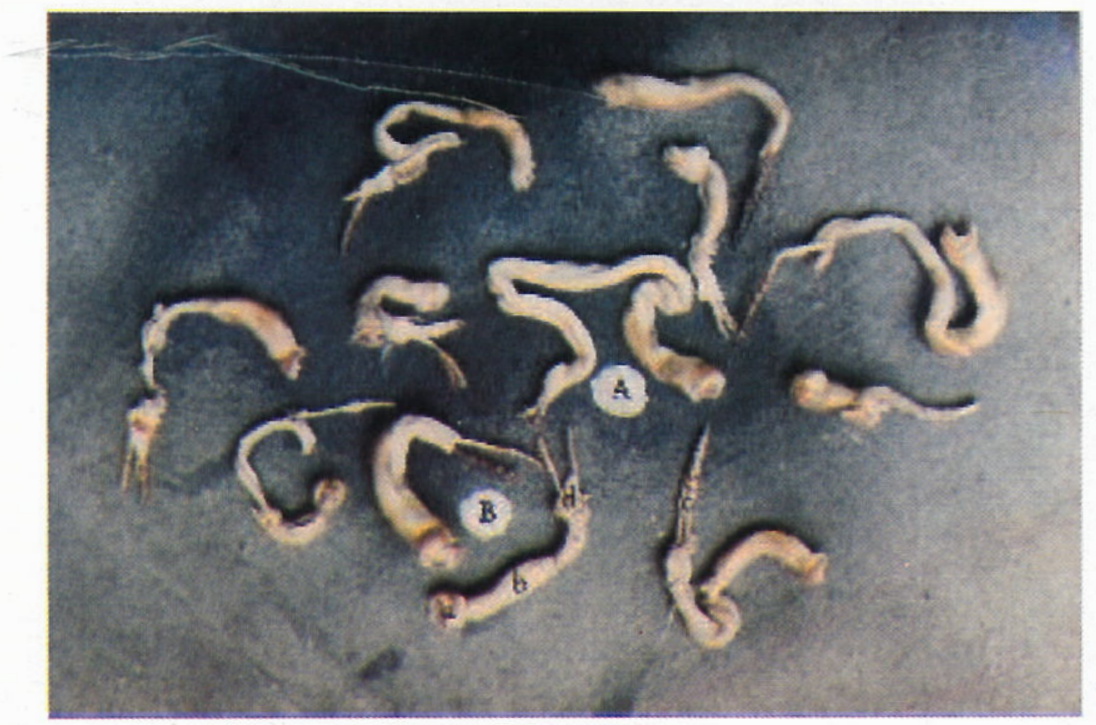

Figure 4. Teredinidae (A) Teredo bartchi Clapp., (B) Bankia cieba Clench. 
The teredinids infestation on the wood and then after going to a very short distance it turned and ran approximately parallel to the grain of the wood and then after going to a very short distance it turned and ran approximately parallel to the grain of the wood. These organisms continuously burrowed the wood, and the burrows were lined with calcareous deposit (a chalk-like substance). The intensity of the infestation indicated the population density, the burrows might twist and turn in any direction and the borers have limited growth. This is related to the study conducted by Adwood and Johnson (1924) which indicated that in a crowded wood, plenty of burrows were twisted and connected to one another, so inner part of the wood resembled spinning webs. Matta and Siriban (1972) stated that the borers might attain a length of $30-100 \mathrm{~cm}$ with a diameter of $2.5 \mathrm{~cm}$. However, if it was crowded the borers might grow only a few $\mathrm{cm}$ with a diameter no more than $1 \mathrm{~cm}$. The wood might be badly affected by the teredinids and yet showed little external signs. The woods with high cellulose content were more preferred by the teredinids because this kind of wood become the source of their food (Turner, 1966). The teredinids attacked the unpreserved wood specimens up to the inner portion of the woods. Southwell and Bultman (1971) stated that the teredinids grew faster than pholadids.

\section{Crustacean}

Other organisms found on the wood specimens were crustaceans. They were Sphaeroma sp. of Sphaeromatidae family. However, there were no apparent symptoms of crustacean infestations on the specimens. The Sphaeroma sp. is $1 \mathrm{~cm}$ long and $0.5 \mathrm{~cm}$ wide. Its looks like slippers. The head is small and the body is segmented. Its tail looks like a board and has a function to cover its hole whenever this organism is disturbed (Figure 5).

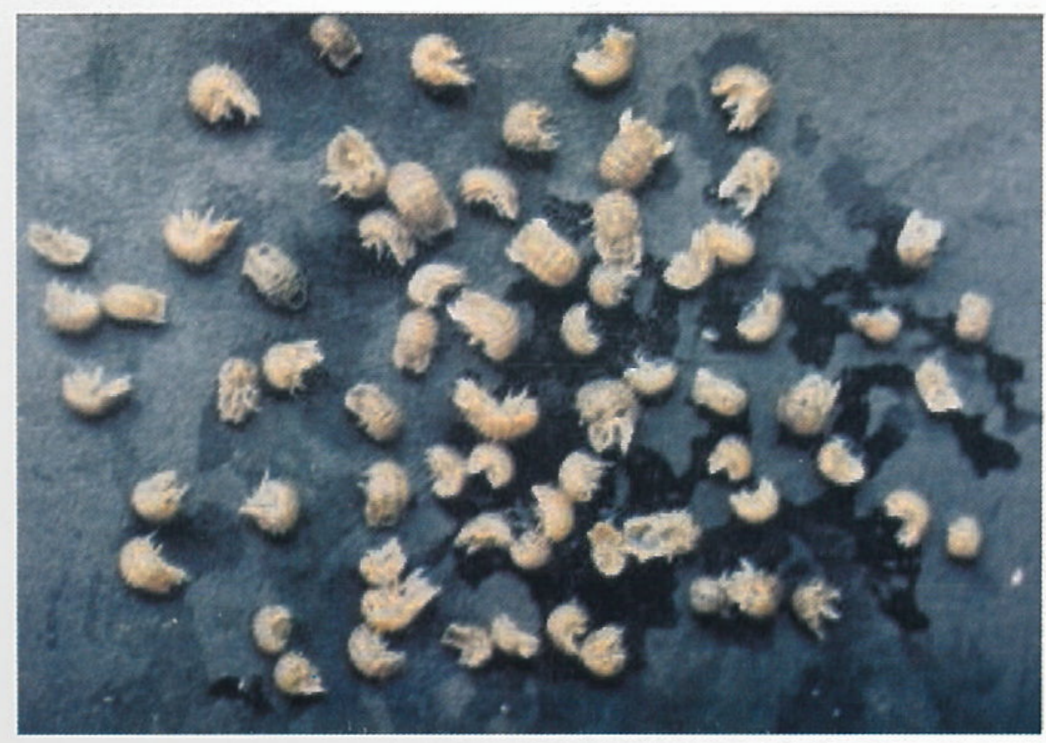

Figure 5. Sphaeroma sp. 


\section{CONCLUSION}

All the untreated wood specimens were not able to prevent marine borer attack in the sea of Ballang Lompo Island sea water, except kandole and lara. Untreated kemiri, pulai and meranti were totally damaged after eight months exposure, while ampupu, marasi, nyatoh, keruing, mahoni, johor and merbau still survived for eight months. Merbatu, jati, kempas and tanjung were resistant for eight months, while kandole and lara were resistant for twelve months.

The attacking borers are Martesia striata Linne. of Pholadidae family, Teredo bartschi Clapp., Dicyathifer manni Wright., and Bankia cieba Clench. of Teredinidae family. The crustaceans found on the specimens were Sphaeroma sp. of the Sphaeromatidae family.

Full-cell process with copper bichromated boron was more effective to prevent marine borer infestation. Samples of kemiri, pulai, keruing and nyatoh were still found after twelve months. Light attack was frequently found on ampupu, marasi, nyatoh, keruing, mahoni and johor.

\section{REFERENCES}

Atwood, W.G. and A.A. Johnson. 1924. Marine Structures Their Deterioration and Preservation. National Research Council Washington, D.C.

Bianchi, A.T.J. 1933. The resistance of some Netherlands East Indian Timbers against the attack of shipworms (Teredo). Fith Pacific Congress, Canada. Pp. 3903-3906.

Findlay, W.P.K. 1985. Preservative of Timber in The Tropic. Martinus Nijhoff/Dr W.Junk Publisher. Dordrect.

Gonggrijp, J.W. 1932. Gegevens Betreffende een Onderzoek Naar Nederlandsch-Indische Houtsoorten, Welke Tegen den Pealworm Bostand Zijn. Mededeeligen van het Boschbouwproeftation. Bogor.

Mata, P.G. and F.R. Siriban. 1972. Resistance of wood to marine borers. Technical Note, No.171. FORPRIDECOME, College, Laguna 3720. Philippines.

Muslich, M. 1994. The Preservative treatment of mahogany lumber (Swietenia macrophylla King.) against marine borers. Unpublished Masters Thesis, University of the Philippines at Los Banos, College, Laguna.

Norman, E. and B. Henningson. 1975. Description of a trial with wood preservatives against marine borers wood boring organisms. Document No. IRG/WP/412, Stockholm, Sweden.

NWPC Standar No. 1.4.2.2/73. Nordic Wood Preservation Council. Standard for Testing of Wood Preservatives. 1973. New Zealand.

Oey, D. S. 1964. Berat jenis dari jenis-jenis kayu Indonesia dan Pengertian beratnya kayu untuk keperluan praktek. Pengumuman No. 1. Lembaga Penelitian Hasil Hutan. Bogor. 
Siau, J.F. 1971. Flow in wood. First edition, Syracus University Press, New York. pp. 11-40.

Panshin, A.J. and C. D Zeeuw. 1980. Textbook of Wood Technology. 14th ed Mc Graw-Hill Book Co.

Smith, D.N.R. and N. Tamblyn. 1970. Proposed Scheme for An International Standard Test for The Resistance of Timbers to Impregnation With Preservatives. Ministry of Technology, Forest Product Research Laboratory. New Zealand.

Southwell, C.R. and J.D. Bultman. 1971. Marine borers resistance of untreated woods over long periods of immersion in tropical waters. Biotropica 3(1):81-107. Naval Research Laboratory, Washington D.C.

Turner, R.D. 1971. Identification of Marine Wood-Boring Mollusks: Marine Borers, Fungi and Fouling Organisms of Wood. Organization for Economics Co-operation and Development. Paris.

1966. A Survey and Illustrated Catalogue of The Teredinidae. Harvard University, Cambridge, Mass.

Wilkinson, J.G. 1979. Industrial Timber Preservation. Associated Business Press. London. 
